\section{Література}

1. Єрмоленко С. Я. Нариси з української словесності: стилістика та культура мови / С. Я. Срмоленко. - К. : Довіра, 1999. - С. 245.

2. Мельничайко В. Я. Мовний розвиток особистості: завдання і засоби / В. Я. Мельничайко // Мовна освіта в контексті завдань української середньої і вищої школи : матеріали науково-практичної конференції. - Тернопіль, 1995. - C. $3-11$.
3. Огієнко І. Українськакультура / І. Огієнко.-К., 1992.-С. 346.

4. Огієнко І. Наука про рідномовні обов' язки. Рідномовний Катехізис для вчителів, робітників пера, духовенства, адвокатів, учнів і широкого громадянства / I. Огієнко // Слово. - 1991. - Ч. 13. - Липень. - С. 4-5.

5. Система виховання національної самосвідомості учнів загальноосвітньої школи. Методичний посібник для вчителів / за ред. академіка Д. О. Тхоржевського. -К., 1999. - С. 134.

УДК 37.041:37.026

\title{
САМОНАВЧАННЯ ЯК МОТИВАЦІЙНА СКЛАДОВА ЯКІСНОЇ ОСВІТИ
}

\author{
Л. Р. Шостакович-Корецька, В. В. Маврутенков, А. В. Чергінець, І. В. Будаєва, \\ О. М. Якуніна, О. В. Шевельова
}

Дніпропетровська державна медична академія

\section{SELF-EDUCATION AS A MOTIVATION COMPONENT OF HIGH QUALITY EDUCATION}

\author{
L. R. Shostakovych-Koretska, V. V. Mavrutenkov, A. V. Cherhinets, I. V. Budayeva, \\ O. M. Yakunina, O. V. Sheveliova \\ Dnipropetrovsk State Medical Academy
}

\begin{abstract}
У роботі надано аналіз анонімного анкетування 344 респондентів студентів старших курсів медичного факультету, інтернів та лікарів для визначення якості регулярної самостійної теоретичної професійної підготовки. Доведено, що більшість студентів та лікарів не мають “звички” до самостійної теоретичної професійної підготовки, що відображає низьку мотивацію до якісного навчання. Головним засобом самостійної професійної освіти для студентів та інтернів $є$ інтернет (48,5 \%), і тільки 25 \% респондентів користуються з цісю метою друкованою фаховою літературою.

The analysis of anonymous questionnaire of 344 respondents - senior students of medical academy, interns and doctors was performed in the research with the goal of determining of the quality of regular self-performed theoretical professional education. It was shown that most of the students and doctors do not have "habit" of self-performed theoretical professional education, which reflects low motivation to high-quality education. The main source for self-performed professional education for students and interns is internet $(48,5 \%$ ), and only $25 \%$ of the respondents use printed specialized literature for this goal.
\end{abstract}

Вступ. Освіта є результатом навчання, тому реформа вищої освіти, яка розпочалась в Україні, спрямована, насамперед, на зміну у дидактичному (навчальному) процесі. Але виникає питання, яка роль в цій реформі належить головному об' єкту педагогіки - студенту, роль “глини” або “каталізатора" навчального процесу? Це не риторичне запитання, оскільки процес навчання $є$ специфічно організованим взаємодійством, при якому відбувається передача теоретичних знань та практичних навичок від викладача студенту 3 метою формування останнього як освіченоїлюдини.

Суть дидактичного процесу, на наш погляд, достатньою мірою висловлює така формула (В. П. Безпалько):

$$
\text { ДП=М+Аф+Ак, де }
$$

ДП - дидактичний процес, М - мотивація студента до навчання, Аф - алгоритм функціонування (навчально-пізнавальна діяльність студента), Ак - алгоритм керівництва (діяльність викладача по керів-

(с Л. Р. Шостакович-Корецька, В. В. Маврутенков, А. В. Чергінець та ін. 
ництву навчанням), яка демонструє, що мотивація студента до навчання є атрибутною складовою якісної освіти. Однією з ознак, що дозволяє оцінити мотивацію студентів до якісного навчання, можна вважати наполегливість у самостійній позааудиторній роботі. Таким чином, визначення мотиваційних зусиль до навчання є актуальним аспектом у галузі психології та прикладної педагогіки [1-4].

Метою даної роботи було оцінити якість самостійної позааудиторної роботи у процесі підготовки медичного фахівця.

Основна частина. Нами проведено анкетування 367 респондентів, з яких 190 студентів п’ятого та 140 - шостого курсів медичного факультету бюджетної та контрактної форми навчання, 14 інтернів-педіатрів, а також 23 лікарі-інфекціоністи.

Анкету було розроблено власноруч авторами дослідження. Вона містила такі відомості про респондента, як вік, стать, курс навчання (фах спеціаліста) та запитання: орієнтир у виборі професії лікаря; назва фахової книги, яку читає або прочитав за останній місяць; назву фахової журнальної статті, яку читає або прочитав за останній місяць; фаховий сайт(и), яким користується респондент; знання іноземної мови; яку лікарську спеціальність обрано; оцінка викладання та організації навчального процесу на кафедрі (незадовільно, задовільно, добре, відмінно).

Анкетування відбувалось анонімно, виключно серед громадян України на добровільних умовах. Серед студентів анкетування проводилось тільки по закінченню навчання на кафедрі та отримання студентом залікової оцінки.

Результати анкетування показали, що в гендерному аспекті серед респондентів переважали жінки (3,3:1), а середній вік 3 числа студентів та інтернів становив 23 роки, серед лікарів-інфекціоністів - 47 років.

Аналіз відповідей показав, що пріоритетом в обранні професії лікаря для більшості респондентів був соціальний статус професії (табл. 1).

Таблиця 1. Мотиви, що вплинули на професійну орієнтацію

\begin{tabular}{|l|c|c|c|c|}
\hline Контингент респондентів & $\begin{array}{c}\text { Соціальний статус } \\
\text { професії }\end{array}$ & $\begin{array}{c}\text { Фінансова } \\
\text { зацікавленість }\end{array}$ & $\begin{array}{c}\text { Мрія } \\
\text { дитинства }\end{array}$ & Iнше \\
\hline Студенти 5 курсу (190) & $138(72,6 \%)$ & $15(7,9 \%)$ & $25(13,2 \%)$ & $12(6,3 \%)$ \\
\hline Студенти 6 курсу (140) & $74(52,8 \%)$ & $33(23,6 \%)$ & $13(9,3 \%)$ & $20(14,3 \%)$ \\
\hline Лікарі-інтерни (14) & $5(35,7 \%)$ & $3(21,4 \%)$ & $5(35,7 \%)$ & $1(7,2 \%)$ \\
\hline Разом: 344 & $217(63,1 \%)$ & $51(14,8 \%)$ & $43(12,5 \%)$ & $33(9,6 \%)$ \\
\hline
\end{tabular}

Причому $66,8 \%$ студентів V курсу та 80 \% студентів VI курсу медичного факультету вже визначились з обраним профілем (спеціалізацією) майбутньої роботи. Отримані факти вказують на те, що у нашому суспільстві, попре все, серед молоді, яка прагне до отримання вищої освіти, домінують моральні цінності та соціальна значимість майбугньої професії. Визначеність 3 фахом майбугньої лікарської професії у переважної більшості респондентів в поєднанні з соціальною спрямованістю професійноїорієнтаціїдає всіпідстави очікувати відповідальне ставлення до навчання.

Визначення реального ставлення студента до навчання, як єдиного шляху досягнення головної мети - отримання якісної освіти, яка гарантує соціальні перспективи і професійну здатність, на наш погляд, мож- ливо через призму “звички” до читання додаткової літератури у вільний час. Причому ми не враховували читання підручника або навчального посібника 3 дисципліни в період навчання на кафедрі. Тому в анкетах було зроблено наголос на конкретні посилання щодо книги, журнальної статті та спеціалізованих медичних сайтів, які базуються на принципах доказовості, а також знання іноземної мови. Результати опитування в цьому ракурсі, на жаль, не виправдали сподівань щодо наполегливості в самостійній освіті, як 3 боку студентів та інтернів, так i “кваліфікованих" лікарів (табл. 2).

Так, $75 \%$ респондентів із загального числа опитаних не мають навичок щодо регулярного читання книг. Особливо невтішним є той факт, що тільки

Таблиця 2. Показники професійної самоосвіти

\begin{tabular}{|l|c|c|c|c|}
\hline \multirow{2}{*}{ Контингент респондентів } & \multicolumn{2}{|l|}{ Прочитано за попередній місяць } & \multirow{2}{*}{$\begin{array}{c}\text { Використання } \\
\text { інтернет-ресурсів }\end{array}$} & $\begin{array}{c}\text { Володіння } \\
\text { іноземною мовою }\end{array}$ \\
\cline { 1 - 3 } Студенти 5 курсу (190) & $48(25,3 \%)$ & $7(3,7 \%)$ & $112(58,9 \%)$ & $58(30,5 \%)$ \\
\hline Студенти 6 курсу (140) & $30(21,4 \%)$ & $9(4,3 \%)$ & $48(34,3 \%)$ & $45(32,1 \%)$ \\
\hline Лікарі-інтерни (14) & $1(7,1 \%)$ & $2(14,2 \%)$ & $6(42,9 \%)$ & $5(35,7 \%)$ \\
\hline Лікарі-інфекціоністи (23) & $9(39,1 \%)$ & $7(30,4 \%)$ & $1(4,3 \%)$ & $3(13,0 \%)$ \\
\hline Разом: 367 & $88(23,9 \%)$ & $25(6,8 \%)$ & $167(45,5 \%)$ & $111(30,2 \%)$ \\
\hline
\end{tabular}


близько 10 \% лікарів-інтернів читають фахові книги 3 медицини. Поясненням щодо причин відсутності “звички читати” книги з боку студентів та лікарів зводилось, насамперед, до “недостатності” часу, великої вартості книг та швидкої втрати з часом актуальності наданої інформації, а також використання інтернет-ресурсів. Ще більш драматично виглядає відсутність “звички” регулярно читати фахові видання майже у всіх респондентів (93\%). Перешкодами до використання періодичної фахової літератури в якості професійної самоосвіти, згідно 3 думкою більшості студентів та лікарів, були майже ті ж самі причини: недостатність часу для відвідування бібліотеки та роботи в читальному залі, а також вартісна підписка на журнали та використання інтернет-ресурсів. Відносно більша кількість читання періодичної фахової літератури “кваліфікованими” лікарями пояснюється активністю фармацевтичних компаній та фірм, які розповсюджують дані щодо власної продукції шляхом безкоштовного надання медичних журналів, в яких міститься корпоративна інформація. Психологи в галузі педагогіки відмічають вкрай важливе значення звички щодо регулярного читання літератури, як головного засобу формування творчих та професійних здібностей людини. Процес читання з точки зору нейрофізіології є великою інтелектуальною роботою, внаслідок якої у нашому мозку виникають нові асоціативні зв' язки, розвивається воля та пам'ять, а також формуються основи суто людсь- ких понять, наприклад, моралі. Як зазначалось вище, однією з головних об' єктивних причин, що обумовлюють зниження інтересу студентів до використання книг та журналів в якості засобів самоосвіти, $€$ існування інтернет-ресурсів. В підтвердження цьому є той факт, що кількість студентів та інтернів, що використовують інтернет, в 10 разів вище, ніж серед "кваліфікованих" лікарів. Але незважаючи на цей факт, кількість студентів та інтернів, які використовують інтернет з метою професійної самоосвіти, досить мала і складає менше 50 \%. Аналіз “якості" вказаних студентами медичних сайтів, якими вони користуються для професійної самоосвіти, показав, що усі вони були російськомовними і досить часто не відповідали принципам доказової медицини. Також в жодному випадку респондентами не була вказана іноземна література або іноземний сайт, що, ймовірно, пов'язано з низьким рівнем вільного володіння європейськими іноземними мовами серед студентів $\mathrm{i}$ інтернів.

Виявилось, що причини низької активності студентів та лікарів-інтернів щодо самостійної професійної позааудиторної роботи не пов' язані з недоліками в іншій складовій дидактичного процесу (ДП) - алгоритму керівництва (Ак), тобто організації навчально-методичного процесу. Про це свідчать результати опитування, де близько $90 \%$ студентів та лікарів-інтернів оцінили організацію навчально-методичного процесу на кафедрі як добру або відмінну (табл. 3).

Таблиця 3. Оцінка викладання та організації навчального процесу на кафедрі

\begin{tabular}{|l|c|c|c|c|}
\hline \multicolumn{1}{|c|}{ Контингент респондентів } & Незадовільно & Задовільно & Добре & Відмінно \\
\hline Студенти 5 курсу (190) & 0 & $19(10,0 \%)$ & $75(39,5 \%)$ & $96(50,5 \%)$ \\
\hline Студенти 6 курсу (140) & 0 & $12(8,6 \%)$ & $74(52,8 \%)$ & $54(38,6 \%)$ \\
\hline Лікарі-інтерни (14) & 0 & $7(50,0 \%)$ & $6(42,9 \%)$ & $1(7,1 \%)$ \\
\hline Разом: 344 & 0 & $38(11,0 \%)$ & $155(45,1 \%)$ & $151(43,9 \%)$ \\
\hline
\end{tabular}

Таким чином, за результатами нашого дослідження можна зробити висновок, що студенти V та VI курсів медичного факультету, а також лікарі-інтерни та лікарі не мають “звички” до самостійної теоретичної професійної підготовки, що відображає низьку мотивацію до якісного навчання. Підвищення мотивації до якісного навчання, на нашу думку, можливо за рахунок таких заходів: по-перше, дотримання плану навчальної дисципліни; по-друге, ерудицією і педагогічною майстерністю викладача; по-трете, обміном студентів між вітчизняними та іноземними вищими медичними навчальними закладами, що є більш доступним в умовах кредитно-модульної системи навчання. Вирішення недоліків в організації са- мостійної теоретичної професійної підготовки є суттєвим резервом підвищення ефективності навчального процесу і покращення якості освіти.

Висновки: 1. Студенти V та VI курсів медичного факультету, а також лікарі-інтерни та лікарі недостатньо приділяють уваги регулярній самостійній позааудиторній професійній підготовці.

2. Головним засобом самостійної професійної освіти для студентів та інтернів є електронні засоби інформації (48,5 \%), тоді як друкованою фаховою літературою користується не більш $25 \%$ респондентів.

3. Здібність студента та лікаря до безперервної самостійної теоретичної професійної підготовки слід розглядати як навичку, що відображає кваліфікацію фахівця. 